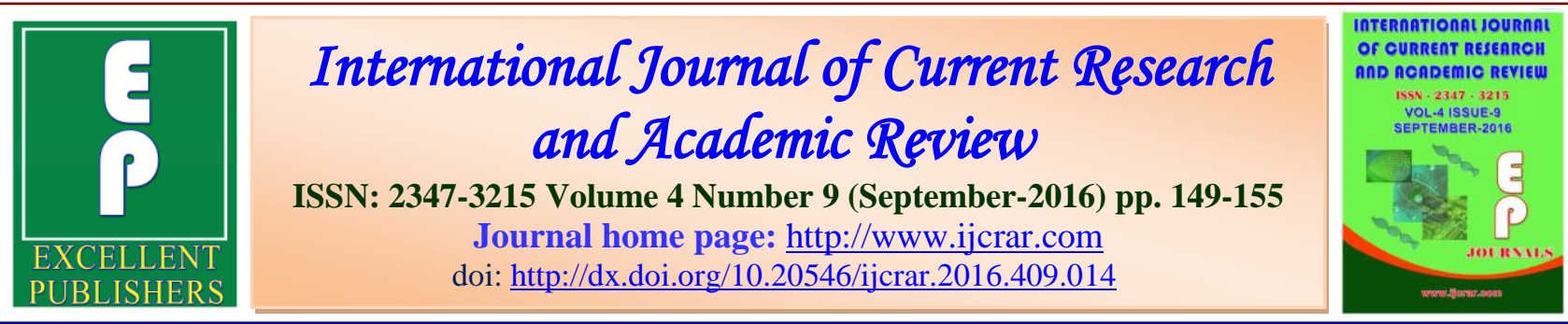

\title{
Evaluation of ABI in Renal Transplantation
}

\author{
Sima Abedi Azar*, Mohammad Emamalizadeh and Akbar Ali Asgharzadeh \\ Department of Internal medicine, Imam Reza Hospital, Faculty of Medicine, Tabriz University \\ of Medical Sciences, Iran
}

*Corresponding author

\begin{tabular}{|c|c|}
\hline KEYWORDS & A B $\mathbf{S} T \mathbf{T} R \mathbf{A} \mathbf{C} \mathbf{T}$ \\
\hline $\begin{array}{l}\text { ABI, } \\
\text { Renal } \\
\text { Transplantation. }\end{array}$ & $\begin{array}{l}\text { Bone is a complicated tissue composed of cells, collagenous matrix, and } \\
\text { inorganic elements. In patients with renal failure, different types of metabolic } \\
\text { bone diseases develop as a result of parathyroid disorders and vitamin D } \\
\text { metabolism. The aim of this study was to evaluation the effect of kidney } \\
\text { transplantation on arterial stiffness before and after kidney transplantation. } \\
\text { Methods and Materials: In a cross-sectional and descriptive-analytical study, } \\
\text { which was conducted in Nephrology department of Tabriz University of } \\
\text { Medical Sciences on patients with kidney transplantation, the effect of kidney } \\
\text { transplantation on arterial stiffness before and after kidney transplantation } \\
\text { was evaluated. Results: } 19 \text { patients were male and } 11 \text { patients were female. } \\
\text { The mean age of male and female patients was } 37.84 \pm 12.04 \text { years and } \\
38.36 \pm 12.04 \text { years, respectively ( } P=0.927) \text {. The mean initial ABI of patients } \\
\text { was } 1.28 \pm 0.24 \text {. The mean ABI of patients after six months was } 1.07 \pm 0.16 \text {. } \\
\text { A significant decrease was observed in the } A B I \text { level of patients as compared } \\
\text { to the initial ABI level six months later }(\mathrm{P}<0.001) \text {. Conclusion: Significant } \\
\text { liner correlation was found between initial } \mathrm{ABI} \text { level and ABI level at six } \\
\text { months after kidney transplantation }(\mathrm{r}=0.765, \mathrm{P}<0.001) \text {. }\end{array}$ \\
\hline
\end{tabular}

\section{Introduction}

Bone is a complex tissue consisting of cells and collagen matrix and inorganic components. This tissue provides vital functions ranging from mechanical support, protecting the vital organs, providing a microscopic environment for hematopoiesis and storage of calcium and other minerals. Level of bone mass show the balance between formation and destruction of bone (1).
In patients with kidney failure, a variety of metabolic bone diseases occur induced by parathyroid disorders and the metabolism of vitamin D. The term renal osteodystrophy includes all types of musculoskeletal disorders that patients with chronic renal failure suffer from. Since GFR decreases in these patients, phosphate gets concentrated and the production of calcitriol is disrupted 
due to hyperphosphatemia (2). As a result of this disorder, serum levels of ionized calcium also decline. The sum of these factors leads to constant stimulation of parathyroid hormone and finally, this leads to hyperplasia of the parathyroid glands and then secondary hyperparathyroidism (3).

Almost all patients with advanced renal failure, have tissue (bone) evidences of secondary hyperparathyroidism and increased parathyroid hormone levels at the beginning of the long and chronic process of dialysis (4-6). This leads to renal osteodystrophy, extramedullary calcification and cardiovascular diseases which increase mortality in patients undergoing dialysis (7).

The aim of this study was to evaluation the effect of kidney transplantation on arterial stiffness before and after kidney transplantation.

\section{Materials and Methods}

In a cross-sectional descriptive-analytical study in the Department of Nephrology, Tabriz University of Medical Sciences on patients undergoing renal transplant, the effect of renal transplant on pre- and postoperative vascular stiffness were examined.

In this study, 30 patients with chronic renal failure, under long-term hemodialysis and candidates for renal transplant were enrolled in the study. Patients with recurrent secondary hyperparathyroidism leading to parathyroidectomy of parathyroid adenoma, recent infection, gastrointestinal disease, malignant diseases, cardiovascular diseases, and advanced atherosclerosis diseases were excluded.

In these blood samples, total serum levels of calcium, phosphate, alkaline phosphatase, albumin and $\mathrm{PPTH}$ were measured before, 1 week, and 6 months after transplant.

\section{The method of determining the ABI}

First, systolic pressure of the upper extremity (brachial artery) is measured by Doppler ultrasound device. Then, systolic pressure of the lower extremity on the same side is measured by Doppler ultrasound device. The numbers obtained are divided to each other.

Patients' ABI values before and 6 months after transplant were measured and analyzed.

\section{Statistical Analysis of Data}

For statistical analysis, descriptive methods (frequency, percentage, mean $\pm \mathrm{SD}$ ) were applied, and the X2 chi-square test and the mean difference test was used for comparison. Repeated measures ANOVA was used to evaluate the trend of variables under study at different times of measurement. All statistical analyses were performed by SPSS v.16 statistical software. The $\mathrm{p}<0.05$ in all cases was considered statistically significant.

\section{Ethical Considerations}

All actions were taken in order to diagnose, treat or follow-up the patients which are routinely performed, therefore, no additional costs were imposed to the patients. In the event that the measures taken would not be necessary in patients' treatment procedure, the required costs were covered by the plan budget. The patients will be assured that their participation in the study is completely voluntary and confidential, and their names and information will not be mentioned anywhere. Personal information of all 
participants during the study will be kept absolutely confidential.

\section{Results and Discussion}

In the present study, the relationship between the effects of renal transplant on vascular stiffness before and after renal transplant was examined and the following results were obtained:

19 patients were male and 11 patients were female. The mean age of the patients was $37.84 \pm 16.21$ years in male patients and $38.36 \pm 12.04$ years in female patients $(\mathrm{P}=0.927)$.

The mean ABI value in patients was $1.28 \pm 0.24$ initially, and $1.07 \pm 0.16$ after 6 months. There was a significant reduction in the $\mathrm{ABI}$ value after six months compared to the initial $A B I$ value $(\mathrm{P}<0.001)$. Evaluation of the studied parameters between the two sexes is shown in Table 1.

There was a significant direct linear relationship between age and $\mathrm{ABI}$ at 6 months after transplant $(\mathrm{P}=0.035$ and $r=0.016)$. There was a significant direct linear relationship between pre-transplant $\mathrm{ABI}$ and $\mathrm{ABI}$ at 6 months after transplant $(\mathrm{P}<0.001$ and $\mathrm{r}=0.765)$. There was a significant reverse linear relationship between pre-transplant $\mathrm{ABI}$ and pretransplant PTH level $(\mathrm{P}=0.046$ and $\mathrm{r}=0.376)$. There was a significant direct linear relationship between pre-transplant $\mathrm{ABI}$ and $\mathrm{Ca}$ level at 6 months after transplant $(\mathrm{P}=0.040$ and $\mathrm{r}=0.378)$. There was $\mathrm{a}$ significant direct linear relationship between $\mathrm{ABI}$ at 6 months after transplant and pretransplant PTH level $(\mathrm{P}=0.012$ and $\mathrm{r}=0.455)$.

In patients with kidney failure, a variety of metabolic bone diseases appear resulted from parathyroid disorders and the metabolism of vitamin D. (8-18).
Bone is a complex tissue consisting of cells and collagen matrix and inorganic components. This tissue provides vital functions ranging from mechanical support, protecting the vital organs, providing a microscopic environment for hematopoiesis and storage of calcium and other minerals. Level of bone mass show the balance between formation and destruction of bone (19).

In patients with kidney failure, a variety of metabolic bone diseases occur induced by parathyroid disorders and the metabolism of vitamin $D$. The term renal osteodystrophy includes all types of musculoskeletal disorders that patients with chronic renal failure suffer from. Since GFR decreases in these patients, phosphate gets concentrated and the production of calcitriol is disrupted due to hyperphosphatemia (20). As a result of this disorder, serum levels of ionized calcium also decline. The sum of these factors leads to constant stimulation of parathyroid hormone and finally, this leads to hyperplasia of the parathyroid glands and then secondary hyperparathyroidism (21). Almost all patients with advanced renal failure, have tissue (bone) evidences of secondary hyperparathyroidism and increased parathyroid hormone levels at the beginning of the long and chronic process of dialysis (22-24).

Bone growth and remodeling is a dynamic process which takes place in result of a balance between bone matrix synthesis by osteoblasts and their resorption by osteoclast multi-core cells (17-18).

In a study by Covic et al in renal transplant and hemodialysis ward of Iasi, Romania in 2005, they stated that vascular stiffness in patients with CRF and renal transplant is a risk factor for cardiovascular diseases (25). 
Int.J.Curr.Res.Aca.Rev.2016; 4(9): $x x-x x$

Table.1 Laboratory finding of patients

\begin{tabular}{|c|c|c|c|c|c|c|c|c|c|}
\hline & \multicolumn{3}{|c|}{ Before } & \multicolumn{3}{|c|}{1 week late } & \multicolumn{3}{|c|}{6 month late } \\
\hline & Male & Female & $\mathrm{P}$ & Male & Female & $\mathrm{P}$ & Male & Female & $\mathrm{P}$ \\
\hline$\overline{\mathrm{iPTH}}$ & $348.58 \pm 309.29$ & $463.22 \pm 278.43$ & 0.32 & $189.05 \pm 151.41$ & $209.09 \pm 120.04$ & 0.71 & $108.68 \pm 62.36$ & $94.36 \pm 101.08$ & 0.63 \\
\hline $\mathrm{Ca}$ & $8.77 \pm 0.78$ & $8.34 \pm 0.75$ & 0.14 & $8.53 \pm 0.43$ & $8.35 \pm 0.34$ & 0.25 & $8.72 \pm 0.30$ & $8.70 \pm 0.33$ & 0.85 \\
\hline $\mathrm{P}$ & $6.02 \pm 1.30$ & $5.83 \pm 2.01$ & 0.75 & $2.82 \pm 0.93$ & $2.42 \pm 0.63$ & 0.21 & $3.06 \pm 0.81$ & $2.60 \pm .63$ & 0.11 \\
\hline BUN & $112.32 \pm 38.93$ & $135.64 \pm 43.79$ & 0.14 & $61.47 \pm 27.96$ & $47.91 \pm 11.67$ & 0.13 & $47.84 \pm 13.50$ & $40.64 \pm 7.81$ & 0.11 \\
\hline $\mathrm{Cr}$ & $8.62 \pm 1.65$ & $10.17 \pm 2.98$ & 0.07 & $1.36 \pm 0.43$ & $1.15 \pm 0.24$ & 0.14 & $1.24 \pm 0.28$ & $1.07 \pm 0.13$ & 0.06 \\
\hline Alb & $4.24 \pm 0.78$ & $4.52 \pm 0.43$ & 0.27 & $3.55 \pm 0.50$ & $3.62 \pm 0.22$ & 0.68 & $3.96 \pm 0.29$ & $3.71 \pm 0.25$ & 0.02 \\
\hline Alp & $380.89 \pm 367.38$ & $393.36 \pm 245.78$ & 0.92 & $201.00 \pm 138.30$ & $173.73 \pm 62.91$ & 0.54 & $174.95 \pm 82.80$ & $198.09 \pm 61.66$ & 0.42 \\
\hline
\end{tabular}

Fig.1 Pattern of ABI changes at before and 6 month late

Estimated Marginal Means of MEASURE_1

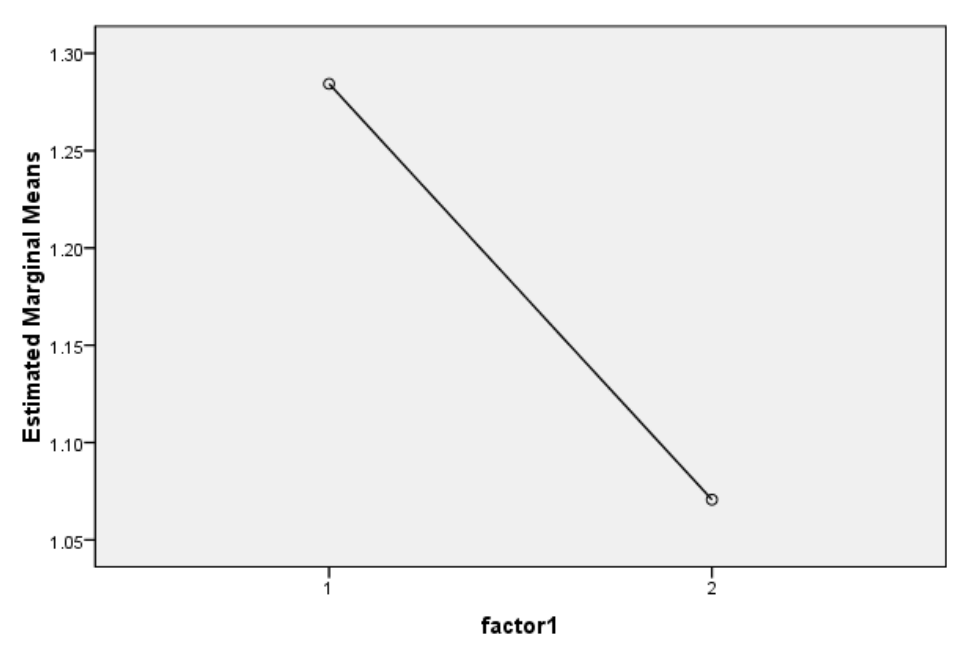


Hujairi et al reported that cardiovascular diseases are one of the major causes of mortality in patients with CRF and vascular stiffness and vascular calcification is common in these patients (26).

In this study, the mean initial $A B I$ in patients was $1.28 \pm 0.24$. The mean $\mathrm{ABI}$ at six months later in patient was $1.07 \pm 0.16$.

In a study by Premuzic et al in the Department of Nephrology of Zagreb, Croatia in 2015, they indicated that vascular stiffness in hemodialysis patients was significantly higher (27).

In this study, there was a significant reduction in $\mathrm{ABI}$ at six months later compared to the initial $\mathrm{ABI}$ in patients $(\mathrm{P}<0.001)$.

Birdwell et al, evaluating vascular stiffness in patients with CRF after renal transplant, stated that vascular stiffness in these patients does not develop in the first year after transplant (28).

There was a significant direct linear relationship between pre-transplant $\mathrm{ABI}$ and ABI at 6 months after transplant $(\mathrm{P}<0.001$ and $r=0.765)$. There was NO linear relationship between pre-transplant $\mathrm{ABI}$ and OPG before the transplant $(\mathrm{P}=0.080)$, at one week $(\mathrm{P}=0.920)$, and at 6 months $(\mathrm{P}=0.306)$ after transplant. There was NO linear relationship between $\mathrm{ABI}$ at 6 months after transplant and OPG before the transplant $(\mathrm{P}=0.269)$, at one week $(\mathrm{P}=0.758)$, and at 6 months $(\mathrm{P}=0.435)$ after transplant.

\section{Conclusion}

19 of patients were male and 11 were female. The mean age of patients was $38.03 \pm 14.60$ years. The mean ABI at the beginning and six months later was
$1.28 \pm 0.24$ and $1.07 \pm 0.16$ respectively. There was a significant reduction in the ABI value after six months compared to the initial ABI value. There was a significant direct linear relationship between pre-transplant $\mathrm{ABI}$ and ABI at 6 months after transplant.

\section{Recommendations}

According to the results obtained, measurement of $\mathrm{ABI}$ in transplant patients is recommended. As well, conduction of further studies is recommended with larger sample sizes and longer follow-up duration.

\section{References}

1.Nijweide PJ, Burger EH, Feyen JH.1986. Cells of bone: proliferation, differentiation, and hormonal regulation. Physiological Reviews, 66, 855-886.

2.Fu GK, Lin D, Zhang MY, Bikle DD, Shackleton CH, et al.1997. Cloning of human 25-hydroxyvitamin D-1 alphahydroxylase and mutations causing vitamin D-dependent rickets type 1. Mol Endocrinol, 11, 1961-1970.

3.Feinfeld DA, Sherwood LM.1988. Parathyroid hormone and $1,25(\mathrm{OH}) 2 \mathrm{D} 3$ in chronic renal failure. Kidney Int, 33,1049-1058

4.Reiss E, Canterbury JM, Egdahl RH. 1968. Experience with a radioimmunoassay of parathyroid hormone in human sera. Trans Assoc Am Physicians, 81, 104-1 14.

6.Arnaud CD.1973. Hyperparathyroidism and renal failure. Kidney Int, 4, 89-95.

7.Ellis HA, Peart KM.1973. Azotaemic renal osteodystrophy: a quantitative study on iliac bone. J Clin Pathol, 26, 83- 101.

8.Simonet WS, Lacey DL, Dunstan CR, Kelley M, Chang MS, Lüthy $\mathrm{R}$, Nguyen HQ, et al.1997. Osteoprotegerin: a novel secreted 
Int.J.Curr.Res.Aca.Rev.2016; 4(9): $x x-x x$

protein involved in the regulation of bone density. Cell, 89(2), 309-19.

9. Yao Y, Wang G, Wang C, Zhang H, Liu C (2011). Synergistic enhancement of new bone formation by recombinant human bone morphologic protein-2 and osteoprotegerin in trans0sutural distraction ontogenesis : a pilot study in dogs. J Oral Maxillofac Surg, 69, 446-455.

10.Coen G, Ballanti P, Balducci A (2002). Serum osteoprotegerin and renal osteodystrophy. Nephrol Dial Transplant, 17, 233-238.

11.Seidel C, Hjertner O, Abildgaard N, Heickendorff L, Hjorth M, Westin J(2001). Serum osteoprotegerin levels are reduced in patients with multiple myeloma with lytic bone disease. Blood, 98, 2269-71.

12.Szulc P, Hofbauer LC, Heufelder AE, Roth S, Delmas PD(2001). Osteoprotegerin serum levels in men: correlation with age, estrogen, and testosterone status. J. Clin. Endocrinol. Metab, 86, 3162-5.

13- Pearse RN, Sordillo EM, Yaccoby S, Wong BR, Liau DF, Colman N, et al(2001). Multiple myeloma disrupts the TRANCE/ osteoprotegerin cytokine axis to trigger bone destruction and promote tumor progression. Proc. Natl. Acad. Sci, 98, 11581-6.

14.Kazama JJ, Maruyama H, Gejyo $\mathrm{F}(2001)$. Osteoclastogenesis and osteoclast activation in dialysis-related amyloid osteopathy. Am. J. Kidney Dis, 38(1), 156-60.

15.Price PA, June HH, Buckley JR, Williamson MK(2001). Osteoprotegerin inhibits artery calcification induced by warfarin and by vitamin D. Rev. Invest. Clin, 4, 362-9.
16.Kostenuik PJ, Capparelli C, Morony S, Adamu S, Shimamoto G, Shen V, et al(2001). OPG and PTH-(1-34) have additive effects on bone density and mechanical strength in osteopenic ovariectomized rats. Endocrinology, 142, 4295-304.

17.Kong YY, Boyle WJ, Penninger JM(1999). Osteoprotegerin ligand: a common link between osteoclastogenesis, lymph node formation and lymphocyte development. Immunol Cell Biol, 77,188-93.

18. Takahashi N, Udagawa N, Suda T(1999). A new member of tumor necrosis factor ligand family, ODF/OPGL/TRANCE/RANKL, regulates osteoclast differentiation and function. Biochem Biophys Res Commun, 256,449-55.

19.Burger EH, Feyen JH. (1986) Cells of bone: proliferation, differentiation, and hormonal regulation. Physiological Reviews, 66, 855-886.

20.Fu GK, Lin D, Zhang MY, Bikle DD, Shackleton CH, et al (1997) Cloning of human 25-hydroxyvitamin D-1 alpha-hydroxylase and mutations causing vitamin D-dependent rickets type 1. Mol Endocrinol, 11:19611970.

21.Feinfeld DA, Sherwood LM (1988) Parathyroid hormone and $1,25(\mathrm{OH}) 2 \mathrm{D} 3$ in chronic renal failure. Kidney Int, 33,1049-1058.

22.Reiss E, Canterbury JM, Egdahl RH(1968). Experience with a radioimmunoassay of parathyroid hormone in human sera. Trans Assoc Am Physicians, 81, 104-1 14.

23.Arnaud CD(1973). Hyperparathyroidism and renal failure. Kidney Int, 4, 89-95.

24.Ellis HA, Peart KM(1973). Azotaemic renal osteodystrophy: a quantitative 
study on iliac bone. J Clin Pathol, 26, 83-101.

25.Covic A, Gusbeth-Tatomir P, Goldsmith DJ(2005). Arterial stiffness in renal patients: an update. Am J Kidney Dis, 45(6),965-77.

26.Hujairi NM, Afzali B, Goldsmith DJ(2004). Cardiac calcification in renal patients: what we do and don't know. Am J Kidney Dis,43(2),234-43.

27.Premuzic V, Leko N, Stipancic

Z, Ivkovic V, Teskera T, Vinkovic M, Barisic M. 2015. Arterial stiffness in patients with endemic nephropathy undergoing

Hypertens, 33(1), hemodialysis. e63.

$J$ 10.1097/01.hjh.0000467515.13639.9c. 28. Birdwell KA, Jaffe G, Bian A, Wu P, Ikizler TA(2015). Assessment of arterial stiffness using pulse wave velocity in tacrolimus users the first year post kidney transplantation: a prospective cohort study. BMC Nephrol, 16, 93. doi: 10.1186/s12882015-0092-7.

\section{How to cite this article:}

Sima Abedi Azar, Mohammad Emamalizadeh and Akbar Ali Asgharzadeh. 2016. Evaluation of ABI in Renal Transplantation. Int.J.Curr.Res.Aca.Rev.4(9): 149-155. doi: http://dx.doi.org/10.20546/ijcrar.2016.409.014 